\title{
KARAKTERISASI, ANALISIS GEN 16S-rRNA BAKTERI BL542 DAN EVALUASI EFEK BAKTERISIDANYA TERHADAP Vibrio harveyi PENYEBAB PENYAKIT PADA UDANG WINDU (Penaeus monodon)
}

\author{
Muliani, Nurhidayah, dan Muharijadi Atmomarsono
}

\begin{abstract}
ABSTRAK
Penelitian bertujuan untuk mengetahui karakteristik, mengevaluasi efek bakterisida, dan menentukan posisi relatif isolat BL542 melalui analisis sekuen 16S-rRNA. Penelitian ini terdiri atas beberapa tahapan kerja yaitu: (1) karakterisasi fisiologi dan biokimia, (2) uji sensitivitas terhadap antibiotik, (3) uji daya hambat isolat BL542 terhadap V. Harveyi, (4) uji patogenisitas isolat BL542 terhadap larva udang, (5) uji tantang secara in vitro maupun secara in vivo isolat BL542 dengan V. Harveyi, (6) analisis gen 16S-rRNA isolat BL542. Hasil penelitian menunjukkan bahwa isolat BL542 termasuk bakteri gram negatif yang berbentuk batang pendek, indol negatif, tidak motil, katalase negatif, oksidase positif, bersifat proteolitik, amilolitik, dan kitolitik. Bakteri ini sensitif terhadap rifampisin, gentamisin, klorampenikol, dan eritromisin, tetapi resisten terhadap furazolidon pada dosis $25 \mathrm{mg} / \mathrm{L}$. Hingga konsentrasi $10^{9} \mathrm{cfu} / \mathrm{mL}$, isolat BL542 tidak patogen pada larva udang windu stadia PL-7 dan dapat menghambat $V$. harveyi dalam air pemeliharaan larva udang windu. Hasil analisis sekuen gen 16S-rRNA, menunjukkan bahwa isolat BL542memiliki kemiripan (88\%) dengan Pseudoalteromonas sp. Edeep-1.
\end{abstract}

\section{ABSTRACT: Characterization 16S-rRNA gene and analysis of bactericidal effect of BL542 against $V$. harveyi in tiger shrimp (Penaeus monodon). By: Muliani, Nurhidayah, and Muharijadi Atmomarsono}

The aims of this experiment were to characterize, analyze the relative position using 165 rRNA gen sequencing, and evaluate bactericidal effect of BL542 bacteria. The experiment consisted of several steps; (1) biochemical and physiological characterization, (2) antibiotic sensitivity test, (3) inhibition test of BL542 bacteria to V. harveyi, (4) pathogenecity test of BL542 bacteria to tiger shrimp larvae, (5) in vitro and in vivo challenge test of BL542 bacteria against $V$. harveyi (6) 16S-rRNA gen analysis of BL542 bacteria. The results showed that BL542 bacteria was gram negative, short-rod shape, indole negative, non motile, catalase negative, and cytocrome oxidase positive, proteolytic, amylolytic, and chytolytic. This bacteria was sensitive to rifampicin, gentamicin, chloramphenicol and erythromicin but resistant to furazolidone at $25 \mathrm{mg} / \mathrm{L}$. Up to concentration of $10^{9} \mathrm{cfu} / \mathrm{mL}, B L 542$ was not pathogenic to tiger shrimp of PL7 and had inhibitory effect on the growth of $V$. harveyi in the larvae rearing water. Based on 16S-rRNA sequencing, BL542 isolat was closely related (88\%) to DNA sequence of Pseudoalteromonas sp. Edeep-1. KEYWORDS: $\begin{array}{ll}\text { 16S-rRNA gene, bactericide, Vibrio harveyi, Pseudoalteromonas sp. Edeep-1, } \\ \text { tiger shrimp }\end{array}$

\section{PENDAHULUAN}

Penyakit vibriosis pada udang windu bukan hanya terjadi di Indonesia, tetapi juga di negara-negara tetangga seperti Filipina (Lavilla-Pitogo et al., 1990), Thailand (Jiravanichpaisal et at., 1994; Ruangpan, 1998), dan India (Karunasagar et al., 1994).

Berbagai penelitian telah dilakukan untuk mendapatkan metode pencegahan dan penanggulangan penyakit pada udang windu antara lain dengan menggunakan obat-obatan dan antibiotik sebagai anti bakteri (Karunasagar et al., 1994). Pencegahan melalui pengelolaan limbah budi daya udang dengan menggunakan tandon dan biofilter (Chanratchakool et al., 1995; Muliani et al., 1998a), merangsang kekebalan non-spesifik melalui penggunaan vaksin dan imunostimulan (Itami \& Takahashi, 1991; Sung et al., 1994; Devaraja et al., 1998; Salfira, 1998; Vargas-Albores et al., 1998), penggunaan probiotik (Austin \& Day, 1990; LavillaPitogo et al., 1998; Rengpipat et al., 1998; Maeda, 1999), serta penggunaan bahan aktif sponge dan hydrozoan sebagai antibakteri (Ahmad et al., 1995; Muliani et al., 1998b; Suryati et al., 2000).

Pemanfaatan beberapa jenis bakteri yang diisolasi dari berbagai sumber sebagai biokontrol (Devaraja et 
al., 2002) dan penghasil antivibriosis, beberapa tahun terakhir ini telah mulai dirintis. Oclarit et al. (1994) telah mengisolasi bakteri penghasil antibakterial, oAminiphenol dari sponge, Adocia sp. Tjahyadi et al. (1994) melaporkan bahwa populasi $V$. harveyi di lingkungan pemeliharaan udang dapat ditekan dengan cara mengintroduksikan bakteri tertentu yang diisolasi dari perairan laut di sekitar tambak atau pembenihan udang. Selanjutnya Rosa et al. (1997) mengisolasi bakteri penghambat $V$. harveyi dari air laut, air tambak, dan air media pemeliharaan larva. Hala (1999) mengemukakan bahwa $V$. metschnicovii $Z$ dan $M$ yang diisolasi dari larva udang sehat efektif menghambat pertumbuhan dan pelekatan $V$. carchariae YA32.2 (patogen terhadap larva udang) dan dapat mengurangi jumlah larva udang yang mati. Haryanti et al. (2000) telah mengisolasi tiga isolat bakteri yang mampu menghambat pertumbuhan $V$. harveyi pada medium agar dalam cawan petri dan satu di antara tiga isolat tersebut mampu menekan pertumbuhan $V$. harveyi pada media pemeliharaan larva udang. Sedangkan Muliani et al. (2003), telah mengisolasi sedikitnya 15 isolat bakteri laut, baik dari sedimen, air, dan karang yang potensial menghambat pertumbuhan bakteri $\mathrm{V}$. harveyi patogen udang windu. Beberapa isolat bakteri yang diisolasi dari daun mangrove (Muliani et al., 2004) dan tambak (Muliani, 2004b) juga telah dilaporkan memiliki daya hambat terhadap $V$. harveyi. Meskipun demikian pemanfaatan bakteri-bakteri tersebut belum maksimal karena adanya beberapa kendala di antaranya optimalisasi pertumbuhan, kemampuan beradaptasi, dan konsistensi antivibriosis yang dimiliki belum diketahui. Oleh karena itu, karakterisasi dan identifikasi baik secara fisiologi maupun biokimia serta evaluasi sifat bakterisida suatu jenis bakteri perlu dilakukan untuk lebih mempermudah kajian konsistensi dari sifat bakterisida yang dimiliki.

Penelitian ini bertujuan untuk mengetahui karakteristik dan mengevaluasi sifat bakterisida serta menentukan posisi relatif isolat BL542 melalui analisis gen 16S-rRNA.

\section{BAHAN DAN METODE}

\section{Karakterisasi Fisiologi dan Biokimia}

Karakterisasi fisiologi dan biokimia isolat BL542 yang dilakukan adalah pewarnaan gram, oksidase, katalase, indol, motilitas, aktivitas amilolitik, aktivitas protease, dan aktivitas kitinase (Hadioetomo, 1993; Muir, 1996).

\section{Uji Sensitivitas terhadap Antibiotik}

Isolat BL542 diuji sensitivitasnya terhadap gentamisin, klorampenikol, eritromisin, furazolidon, dan rifampisin pada konsentrasi $25 \mathrm{mg} / \mathrm{mL}$. Setiap jenis antibiotik tersebut dicampurkan dalam media SWC (Sea Water Complete) 100\% ( air laut 750 mL, akuades $250 \mathrm{~mL}$, bakto pepton $5 \mathrm{~g}$, ekstrak khamir $1 \mathrm{~g}$, gliserol $3 \mathrm{~mL}$, dan bakto agar $15 \mathrm{~g}$ ) dalam cawan petri yang selanjutnya digunakan sebagai media biakan. Sensitivitas isolat BL542 ditandai dengan tidak adanya pertumbuhan bakteri pada media yang telah dibubuhi dengan antibiotik (minimal 48 jam masa inkubasi).

\section{Uji Daya Hambat Isolat BL542 terhadap V. harveyi}

Bakteri V. harveyi MR5339 ditumbuhkan pada medium TCBSA (Thiosulfate Citrate Bile Sucrose Agar) selama 24 jam. Koloni tunggal yang tumbuh diambil dengan jarum ose dan disuspensikan dalam larutan garam fisiologis $(0,85 \%(\mathrm{w} / \mathrm{v}) \mathrm{NaCl})$. Kemudian disebar pada media SWC 100\% dalam cawan petri, selanjutnya ditaruh paper disk steril yang berdiameter $7 \mathrm{~mm}$. Paper disk ditetesi dengan biakan isolat BL542 sebanyak $10-20 \mathrm{~mL}$ (konsentrasi biakan dalam suspensi sekitar $10^{8}-10^{9} \mathrm{cfu} / \mathrm{mL}$ ). Kemudian diinkubasi pada suhu $28^{\circ} \mathrm{C}$ selama $24-48$ jam, setelah itu zona hambatan yang terbentuk diukur dengan mistar penggaris pada tiga posisi dan selanjutnya diratakan.

\section{Uji Patogenisitas Isolat BL542 terhadap Larva Udang pada Konsentrasi yang Berbeda}

Konsentrasi isolat BL542 yang digunakan pada uji patogenisitas adalah $10^{3}, 10^{5}, 10^{7}$, dan $10^{9} \mathrm{cfu} / \mathrm{mL}$ dengan metode perendaman (Hameed, 1995). Wadah yang digunakan adalah stoples kaca berkapasitas 3 $L$ yang diisi air laut steril dengan kadar garam 28 ppt sebanyak $2 \mathrm{~L}$ dan ditebari dengan larva udang sebanyak 20 ekor/wadah.

Untuk menjaga ketersediaan oksigen, wadah pemeliharaan larva dilengkapi dengan aerasi. Pemberian pakan dilakukan sebanyak dua kali per hari sebanyak $10 \%$ bobot tubuh larva udang. Patogenisitas isolat BL542 terhadap larva udang windu diamati melalui kematian larva udang setelah 24 jam perendaman (Rengpipat et al., 1998) dan dibandingkan dengan kontrol. Penelitian dilakukan dengan rancangan acak lengkap dengan tiga kali ulangan. Sintasan larva udang dianalisis ragamnya dan dilanjutkan dengan uji beda nyata terkecil (Steel \& Torrie, 1981)

\section{Uji Tantang Bakteri $V$. harveyi dengan isolat BL542}

\section{Uji tantang secara in vitro}

Uji tantang secara in vitro dilakukan dengan menggunakan media SWC kaldu 100\% (air laut 750 
$\mathrm{mL}$, akuades $250 \mathrm{~mL}$, bakto pepton $5 \mathrm{~g}$, ekstrak khamir $1 \mathrm{~g}$, gliserol $3 \mathrm{~mL}$ ) dalam labu erlenmeyer. Kepadatan bakteri $V$. harveyi dibuat menjadi $10^{7} \mathrm{cfu} /$ $\mathrm{mL}$ (Rengpipat et al., 1998) dan kepadatan bakteri BL542 dibuat menjadi $10^{8} \mathrm{cfu} / \mathrm{mL}$ (Tjahyadi, 1994; Hala, 1999; Muliani et al., 2003). Populasi V. harveyi dalam wadah diamati pada hari ke-1, 2, 3, dan 4 dengan menggunakan SWC $100 \%$ yang telah ditambah rifampisin sebagai media selektif.

\section{Uji tantang secara in vivo}

Uji tantang secara in vivo dilakukan di dalam akuarium kaca dengan berkapasitas $3 \mathrm{~L}$. Wadah tersebut diisi air laut steril dengan kadar garam 28 ppt sebanyak $2 \mathrm{~L}$, dan ditebari larva udang stadia $\mathrm{PL}$ 7 sebanyak 20 ekor/wadah. Perlakuan dalam penelitian ini terdiri atas $V$. harveyi $\left(10^{7} \mathrm{cfu} / \mathrm{mL}\right)$ ditantang dengan BL542 dengan kepadatan $10^{8} \mathrm{cfu} / \mathrm{mL}$, monokultur $V$. harveyi $\left(10^{7} \mathrm{cfu} / \mathrm{mL}\right)$, dan monokultur larva udang (tidak diinokulasi bakteri). Masing-masing perlakuan diulang tiga kali. Pengamatan populasi bakteri dalam air pemeliharaan larva udang dilakukan setiap 24 jam, sedangkan pengamatan larva udang yang mati dilakukan setelah 96 jam (hari ke-4). Perbedaan tingkat mortalitas larva udang windu setelah 96 jam dianalisis ragam dan dilanjutkan dengan uji beda nyata terkecil (Steel \& Torrie, 1981).

\section{Identifikasi Isolat BL542 secara Molekuler}

Untuk menentukan identitas isolat BL542 berdasarkan sekuen 16S-rRNA, dilakukan analisis yang meliputi beberapa tahapan sesuai dengan metode yang dikemukakan oleh Marchesi et al. (1998) dan telah dimodifikasi oleh Suwanto et al. (2000) yaitu meliputi ekstraksi DNA, amplifikasi gen 16S-rRNA dengan PCR, gene clean dengan metode glass milk, cycle sequensing dengan metode Big Dye, presipitasi DNA, dan sekuensing dengan mesin Sequenser.

\section{Ekstraksi DNA}

Isolat BL542 ditumbuhkan dalam media SWC kaldu. Kultur diinkubasi dalam shaker water bath pada suhu $28^{\circ} \mathrm{C}, 10.000 \mathrm{rpm}$ selama 24 jam. Sel bakteri dipanen dengan mengambil $1 \mathrm{~mL}$ suspensi biakan bakteri, lalu dimasukkan ke dalam Eppendorf volume $1,5 \mathrm{~mL}$. Selanjutnya disentrifugasi dengan kecepatan 6.000 rpm selama 5 menit dan supernatannya dibuang. $\mathrm{Hal}$ ini dilakukan dua kali. Pelet bakteri yang terbentuk kemudian diresuspensi dengan $250 \mathrm{~mL}$ buffer 1 xTE dan $2 \mathrm{mg} / \mathrm{L}$ lisozim, diinkubasi $37^{\circ} \mathrm{C}$ selama 30 menit. Selanjutnya ditambahkan SDS $10 \%$ sebanyak $50 \mathrm{~mL}$ dan $5 \mathrm{~mL}$ Proteinase-K, dibolak-balik sampai bening berlendir. Campuran ini diinkubasi pada suhu $37^{\circ} \mathrm{C}$ selama satu jam (tiap 15 menit dikocok). Setelah itu ditambahkan $65 \mathrm{~mL} \mathrm{NaCl} 5 \mathrm{M}$, dibolak-balik sehingga tercampur dengan baik, kemudian ditambahkan $80 \mathrm{~mL}$ CTAB $10 \%$. Dihomogenkan sampai berwarna putih susu, kemudian diinkubasi pada suhu $65^{\circ} \mathrm{C}$ selama 20 menit. Selanjutnya ke dalam campuran tersebut di tambahkan $650 \mathrm{~mL}$ phenol:chloroform:isoamyl alkohol (25:24:1), dihomogenkan dengan vorteks selama 30 detik, kemudian disentrifugasi dengan kecepatan 5.000 rpm pada suhu ruang selama 10 menit. Supernatan diambil dengan mikro pipet dan dipindahkan ke dalam tabung Eppendorf steril yang telah diisi dengan 600 $\mathrm{mL}$ isopropanol dan dibolak-balik sehingga timbul benang-benang DNA dan dibiarkan pada suhu ruang selama 30 menit. Selanjutnya disentrifugasi dengan kecepatan 5.000 rpm pada suhu ruang dan setelah itu supernatan dibuang. DNA dalam bentuk pelet dicuci dengan $300 \mathrm{~mL}$ ethanol $70 \%$, disentrifugasi selama 5 menit pada suhu ruang dan setelah itu etanol dibuang. Pelet DNA dikering-udarakan atau dengan menggunakan pompa vakum untuk menguapkan etanol yang masih tersisa. Langkah terakhir dalam ekstraksi DNA adalah penambahan akuabides bebas nuklease atau buffer 1xTE atau Elution Buffer (EB) dan selanjutnya DNA disimpan pada suhu $-20^{\circ} \mathrm{C}$ untuk keperluan selanjutnya.

\section{Amplifikasi gen 16S-rRNA dengan PCR}

Sebelum dilakukan amplifikasi gen 16S-rRNA dengan PCR, terlebih dahulu dilakukan pengecekan terhadap DNA yang telah diekstrak melalui elektroforesis gel mini (Suwanto et al., 2000) atau dengan gene Quant. Amplifikasi gen 16S-rRNA dengan PCR digunakan Ready to go PCR beads dengan komponen reaksi terdiri atas dd $\mathrm{H}_{2} \mathrm{O} 23 \mathrm{~mL}$, DNA templet $0,5 \mathrm{~mL} ; 1 \mathrm{~mL} 63 \mathrm{f}$ primer; dan $1 \mathrm{~mL} 1387 \mathrm{r}$ primer. Primer yang digunakan adalah primer universal untuk domain bakteria berupa Forward primer $63 \mathrm{f}$ ( 5 'CAGGCCTAACACATGCAAGTA-3') dan reverse primer 1387r (GGGCGGWTGGTACAAGGC-3') (Marchesi et al., 1998; Suwanto et al., 2000). Semua komponen reaksi dicampur dalam mikrotube dan selanjutnya di running. Proses running pada PCR dilakukan dalam 30 siklus, di mana masing-masing siklus terdiri atas tahap pre start pada suhu $94^{\circ} \mathrm{C}$ selama 2 menit, tahap denaturasi DNA utas ganda pada suhu $92^{\circ} \mathrm{C}$ selama 30 detik, tahap annealing pada suhu $55^{\circ} \mathrm{C}$ selama 30 detik, dan tahap perpanjangan pada suhu $75^{\circ} \mathrm{C}$ selama 1 menit, tahap post PCR pada suhu $75^{\circ} \mathrm{C}$ selama 20 menit, dan tahap stop PCR pada suhu $4^{\circ} \mathrm{C}$. Selanjutnya hasil PCR disimpan pada suhu $-20^{\circ} \mathrm{C}$ (Suwanto et al., 2000).

\section{Pemurnian DNA}

Pada tahapan ini DNA yang telah diamplifikasi dengan PCR di running dalam elektroforesis kemudian dimurnikan dengan metode glass milk. 


\section{Cycle sequensing, presipitasi, dan sekuensing DNA}

Pada tahapan ini pereaksi dan langkah kerja dilakukan berdasarkan metode yang dilaporkan oleh Marchesi et al. (1998) yang telah dimodifikasi oleh Suwanto et al. (2000).

\section{HASIL DAN BAHASAN}

\section{Karakteristik Isolat BL542}

Isolat BL542 diisolasi dari sedimen laut Pulau Balam Lompo, Sulawesi Selatan pada bulan Juli 2001. Isolat ini memiliki ciri-ciri morfologi koloni, berbentuk bundar kecil, tepian licin, elevasi cembung, dan berwarna kuning muda. Hasil uji fisiologi dan biokimia menunjukkan bahwa isolat BL542 termasuk dalam kelompok bakteri gram negatif, sel berbentuk batang, oksidase positif, katalase negatif, indol negatif, tidak bersifat motil, bersifat fermentatif dan amilolitik, dan memproduksi enzim kitinase dan protease. Isolat ini tumbuh pada suhu $40^{\circ} \mathrm{C}$, tetapi tidak tumbuh pada media Thiosulfate Citrate Bile Salt Agar (TCBS-Agar). Pertumbuhan isolat ini pada media SWC agar disajikan pada Gambar 1.

\section{Resistensi Isolat BL542 terhadap Beberapa Antibiotik}

Sifat resistensi terhadap antibiotik diperlukan oleh suatu mikroorganisme untuk mempertahankan sintasannya di alam. Menurut Chythanya et al. (1999), secara alami beberapa jenis mikroorganisme memiliki gen penyandi antibiotik yang dapat melindungi dirinya dari efek pengaruh antibiotik luar. Sifat resistensi terhadap suatu jenis antibiotik dari suatu bakteri perlu diketahui sebelum ditetapkan jenis antibiotik yang akan digunakan sebagai penanda genetik terhadap bakteri tersebut. Hal ini akañ memudahkan untuk menyeleksi bakteri tersebut dari bakteri lain yang secara alami sensitif terhadap antibiotik yang digunakan.

Hasil uji sensitivitas isolat BL542 terhadap beberapa antibiotik menunjukkan bahwa isolat tersebut sensitif terhadap rifampisin, gentamisin, kloramfenikol, dan eritromisin dosis $25 \mathrm{mg} / \mathrm{L}$ dan bersifat resisten terhadap furazolidon pada dosis yang sama. Muliani et al. (2003) telah mengisolasi beberapa jenis bakteri dari air laut dan karang furazolidon termasuk antibiotik yang dilarang keras penggunaannya dalam bidang akuakultur, karena meskipun antibiotik ini tidak bertahan lama dalam air dan cepat terdegradasi, namun antibiotik ini bersifat mutagenik terhadap beberapa organisme (Sze, 2000). Hasil uji sensitivitas sedikitnya 15 isolat bakteri laut yang diisolasi dari air laut, karang, dan sedimen semuanya bersifat sensitif terhadap gentamisin, klorampenikol, dan eritromisin pada dosis $25 \mathrm{mg} / \mathrm{L}$, dan beberapa di antaranya resisten terhadap furazolidon (Muliani et al., 2003).

Hasil uji resistensi terhadap antibiotik, tetrasiklin dan rifampisin dari 45 isolat bakteri yang diisolasi baik dari air laut maupun air pemeliharaan larva udang yang dilakukan oleh Tjahjadi et al. (1994) menunjukkan

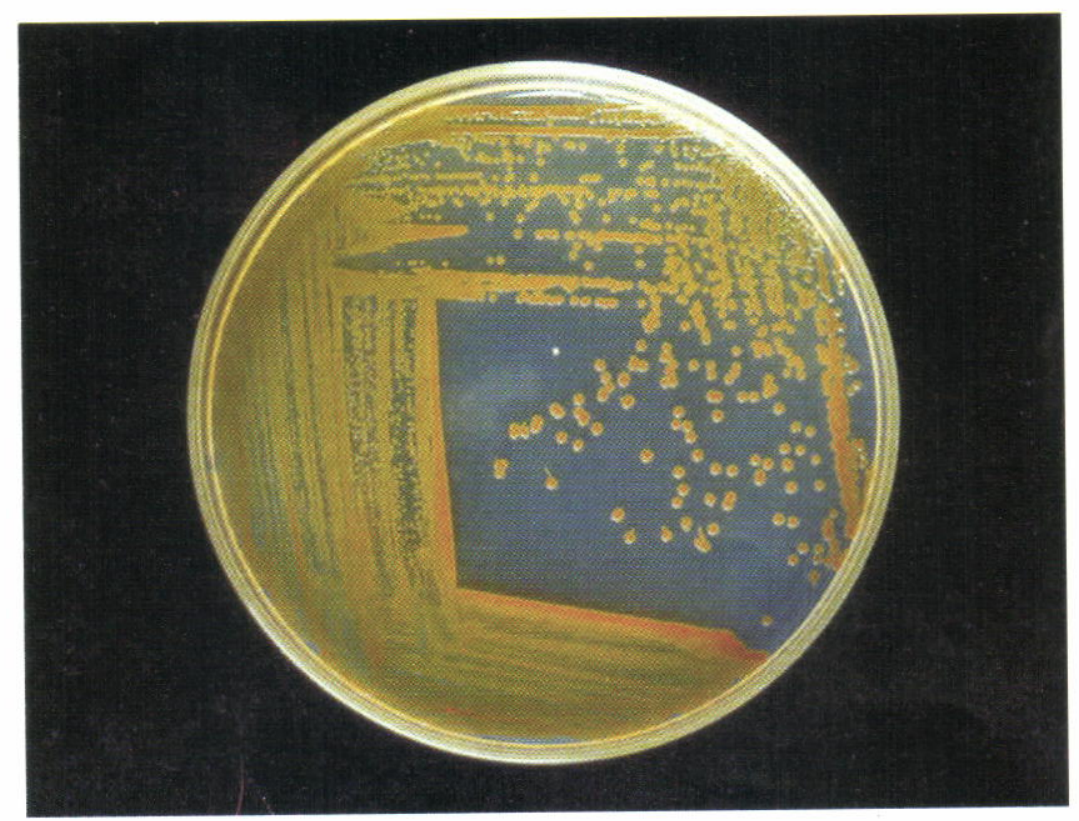

Gambar 1. Penampilan isolat BL542 pada media sea water complete

Figure 1. Performance of BL542 isolate on sea water complete medium 
bahwa semua isolat bersifat resisten terhadap tetrasiklin tetapi hanya beberapa di antaranya yang resisten terhadap rifampisin. Beberapa isolat Vibrio yang diisolasi dari panti perbenihan udang bersifat sensitif terhadap gentamisin dan rifampisin (Hala, 1999).

\section{Uji Daya Hambat Isolat BL542 secara In Vitro pada Cawan Petri}

Hasil uji daya hambat secara in vitro dalam cawan petri menunjukkan bahwa isolat BL542 mampu menghambat pertumbuhan $V$. harveyi MR5339 dengan diameter zona hambatan sebesar $11,5 \mathrm{~mm}$. Muliani (2003) telah mengisolasi beberapa bakteri dari air laut, sedimen laut, dan karang dengan kisaran daya hambat 1,1-11,5 $\mathrm{mm}$.

Berdasarkan hasil uji daya hambat dari filtrat sel isolat BL542 yang tidak menunjukkan aktivitas bakterisida, maka diduga bahwa bakterisida yang dimiliki oleh bakteri ini bersifat intraseluler. Hal yang serupa telah dilaporkan oleh Manefield et al. (2000) di mana suatu senyawa yang dihasilkan secara intra selluler oleh marine algae (Deliscea pulchra), halogenated furanone dapat menghambat ekspresi luminescens dan virulensi $V$. harveyi yang patogen pada udang windu.

\section{Patogenisitas Isolat BL542 terhadap Larva Udang}

Sebelum dilakukan uji tantang dengan Vibrio harveyi MR5339 dalam wadah pemeliharaan larva udang windu, isolat BL542 diuji tingkat patogenisitasnya terhadap larva udang windu pada beberapa konsentrasi (Tabel 1). Pada tabel tersebut terlihat bahwa sampai konsentrasi $10^{9} \mathrm{cfu} / \mathrm{mL}$, isolat BL542 tidak bersifat patogen terhadap larva udang. Hal ini dapat diketahui dengan melihat sintasan larva udang pada semua perlakuan tidak berbeda nyata secara statistik $(P>0,05)$ terhadap kontrol (tanpa pemberian bakteri)

Hasil penelitian oleh beberapa peneliti terdahulu menunjukkan bahwa pada umumnya bakteri yang diisolasi dari air laut dan tambak yang potensial sebagai biokontrol tidak bersifat patogen pada larva udang windu. Rosa et al. (1997) mengemukakan bahwa pada kepadatan $10^{5}, 10^{6}, 10^{7}$, dan $10^{8} \mathrm{cfu} / \mathrm{mL}$ selama 24 jam perendaman semua bakteri kandidat biokontrol yang diuji patogenisitasnya tidak bersifat patogen pada larva udang windu. Demikian pula yang dihasilkan oleh Haryanti et al. (2000), isolat BY-9 sebagai biokontrol tidak bersifat patogen pada larva udang windu setelah inkubasi 12 jam pada konsentrasi $10^{5} \mathrm{cfu} / \mathrm{mL}$

\section{Uji Tantang Isolat BL542 terhadap V. harveyi MR5339}

\section{Uji tantang secara in vitro}

Uji tantang secara in vitro dilakukan menggunakan media kaldu SWC $100 \%$, dengan kepadatan V. harveyi MR5339 $10^{7} \mathrm{cfu} / \mathrm{mL}$ dan isolat BL542 $10^{8} \mathrm{cfu} / \mathrm{mL}$. Berdasarkan hasil uji pendahuluan konsentrasi di bawah $10^{8} \mathrm{cfu} / \mathrm{mL}$, isolat BL542 tidak efektif menghabat perkembangan populasi $V$. harveyi. Hasil uji tantang secara in vitro disajikan pada Gambar 2. Dari gambar tersebut terlihat bahwa populasi $V$. harveyi MR5339 pada perlakuan kombinasi $V$. harveyi MR5339 dengan isolat BL542 menurun dari $10^{7} \mathrm{cful}$ $\mathrm{mL}$ pada hari ke-0 menjadi $1,8 \times 10^{5} \mathrm{cfu} / \mathrm{mL}$ pada hari keempat, sedangkan pada perlakuan tunggal $V$. harveyi MR5339 tidak mengalami penurunan, bahkan terjadi peningkatan sejak pada hari ke-1 sampai hari ke-4. Puncak perkembangan populasi $V$. harveyi MR5339 pada perlakuan tunggal terjadi pada hari ke2 (setelah 24 jam) yaitu mencapai $1,6 \times 10^{9} \mathrm{cfu} / \mathrm{mL}$. Rendahnya populasi $V$. harveyi MR5339 pada perlakuan kombinasi $V$. harveyi MR5339 dengan isolat

Tabel 1. Rata-rata mortalitas (\%) larva udang pada uji patogenisitas isolat BL542 setelah 24 jam perendaman Table 1. Average mortality rate (\%) of tiger shrimp in the pathogenecity test of BL542 bacteria after 24 hours of immersion

\begin{tabular}{cc}
\hline $\begin{array}{c}\text { Konsentrasi sel (cfu/mL) } \\
\text { Cell concentration (cfu/mL) }\end{array}$ & $\begin{array}{c}\text { Mortalitas udang windu (\%) } \\
\text { Tiger shrimp mortality (\%) }\end{array}$ \\
\hline 0 & $6.67^{\mathrm{a}}$ \\
103 & $5.00^{\mathrm{a}}$ \\
105 & $6.67^{\mathrm{a}}$ \\
107 & $6.67^{\mathrm{a}}$ \\
109 & $12.00^{\mathrm{a}}$ \\
\hline
\end{tabular}

Keterangan: Nilai dalam kolom yang diikuti huruf yang sama secara statistik tidak berbeda nyata $(P>0,05)$ Note: Values in the columns followed by similar letters are notsignificantly different $(P>0.05)$ 


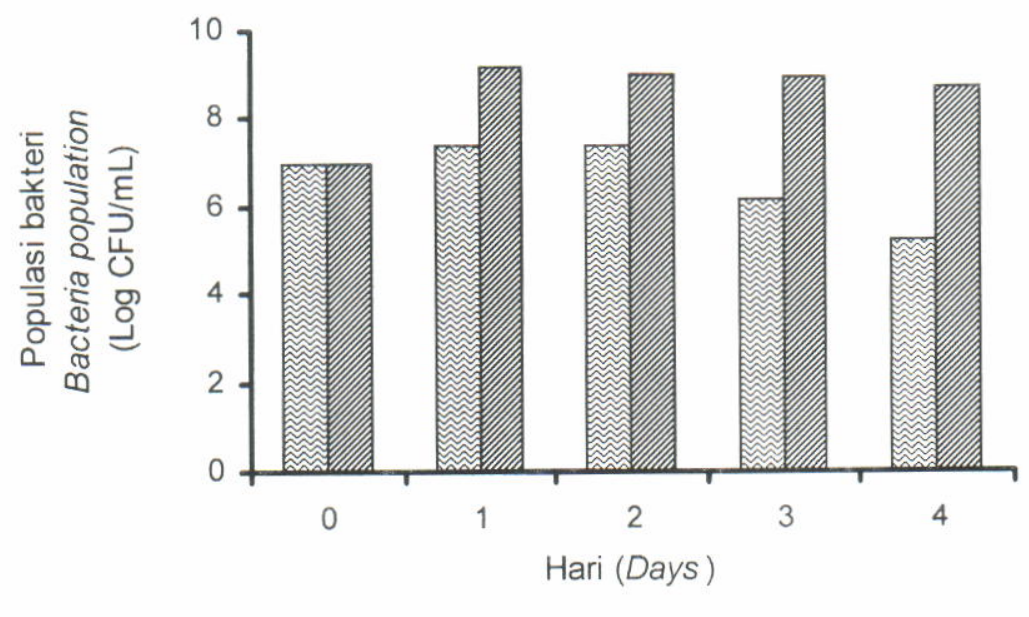

Gambar 2. Perkembangan populasi V. harveyi MR5339 pada uji tantang secara in vitro

Figure 2. Population growth of V. harveyi MR5339 challenged with BL542 bacteria

BL542 menunjukkan bahwa isolat BL542 efektif menekan perkembangan populasi $\mathrm{V}$. harveyi MR5339.

\section{Uji tantang secara in vivo}

Uji tantang secara in vivo dilakukan dengan menggunakan larva udang windu PL-7. Parameter yang diamati adalah populasi $V$. harveyi MR5339 dalam media pemeliharaan dilakukan setiap 24 jam selama 96 jam dan jumlah larva udang yang mati dilakukan setelah 96 jam.

Populasi V. harveyi MR5339 dalam air pemeliharaan larva udang PL-7 selama penelitian disajikan pada Gambar 3. Dari gambar tersebut terlihat bahwa Populasi V. harveyi MR5339 dalam media pemeliharaan yang diberi bakteri BL542 dari awal sampai akhir penelitian lebih rendah dibandingkan dengan populasi V. harveyi MR5339 dalam media pemeliharaan yang tidak diberi bakteri BL542.

Pengamatan jumlah larva yang mati dilakukan setelah 96 jam. Jumlah larva yang mati pada setiap perlakuan disajikan pada Gambar 4. Dari gambar tersebut terlihat bahwa secara deskriptif mortalitas larva udang tertinggi pada perlakuan yang diinokulasi V. harveyi MR5339 tanpa pemberian bakteri BL542 kemudian berturut-turut pada perlakuan yang diinokulasi V. harveyi MR5339 ditambah isolat BL542, kemudian kontrol negatif (tidak ada penambahan bakteri, baik $V$. harveyi MR5339 maupun bakteri BL542). Hal ini senada dengan hasil penelitian yang dilaporkan oleh Abraham (2004), di mana mortalitas

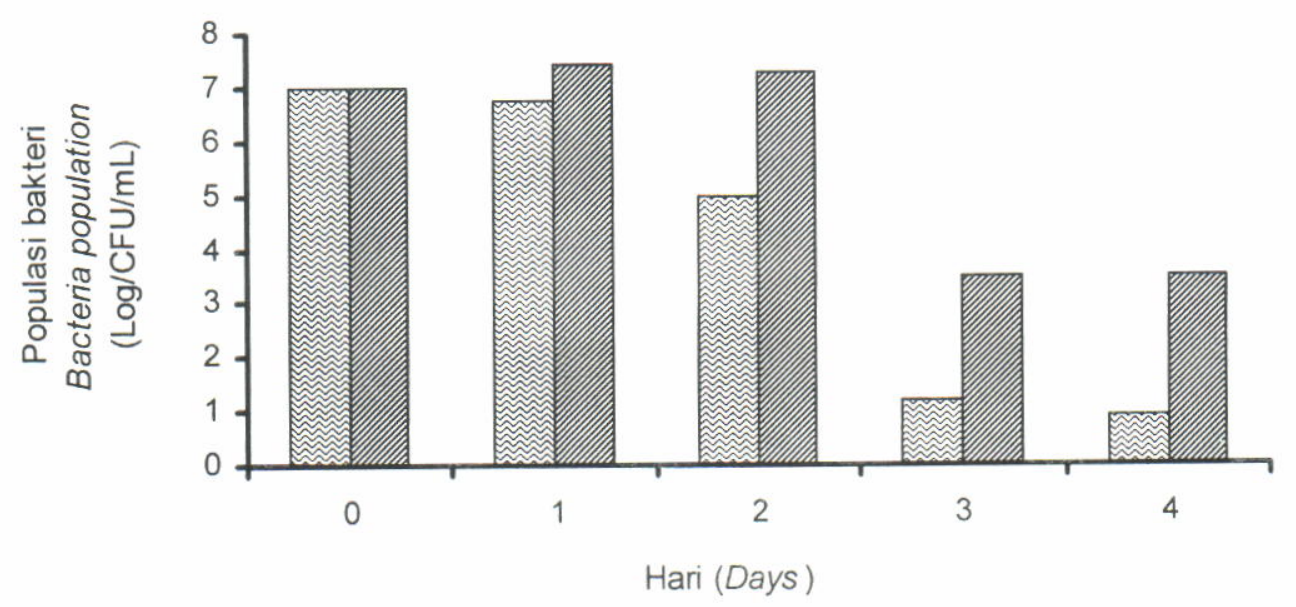

园 V.harveyi + BL542 V. harveyi MR5339

Gambar 3. Populasi V. harveyi MR5339 dalam air pemeliharaan larva udang windu pada uji tantang in vivo

Figure 3. Population of MR5339 in the rearing water of tiger shrimp larvae in in vivo challenged 


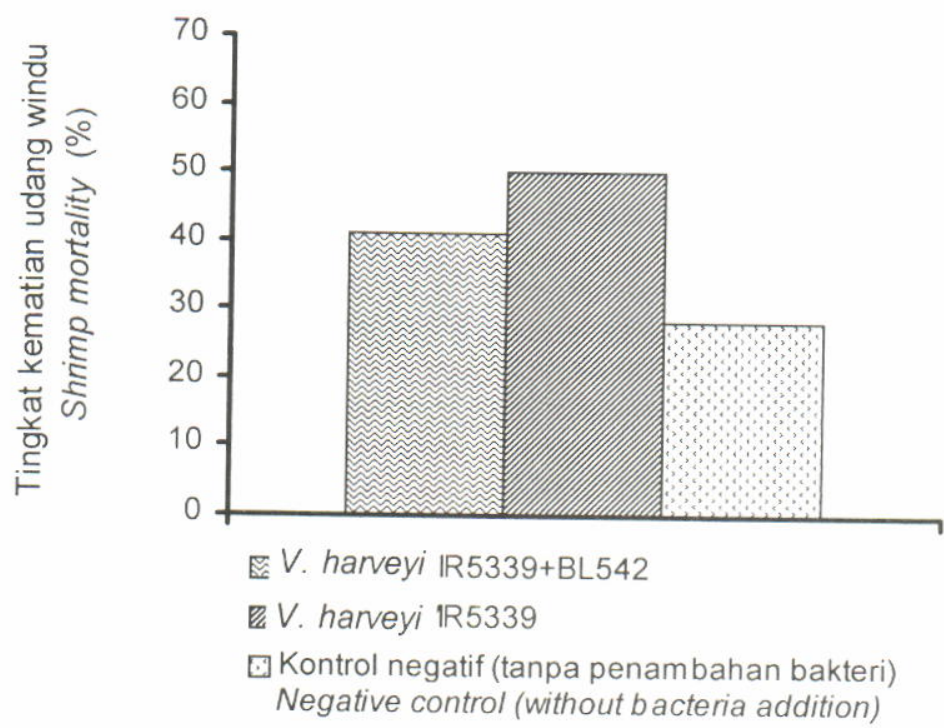

Gambar 4. Rata-rata jumlah larva udang yang mati (\%) setelah 96 jam inokulasi

Figure 4. Average mortality rate of tiger shrimp larvae after 96 hours of inoculation

larva udang windu tertinggi pada perlakuan yang diinokulasi dengan $V$. harveyi $\mathrm{M} 3$ tanpa pemberian Alteromonas sp. P7, kemudian berturut-turut pada perlakuan yang diinokulasi $V$. harveyi M3 ditambah Alteromonas sp. P7, kemudian terrendah pada kontrol negatif (tidak ada penambahan bakteri, baik $V$. harveyi M3 maupun Alteromonas sp. P7)

Namun demikian hasil analisis statistik tidak menunjukkan adanya perbedaan yang nyata $(P>0,05)$ terhadap tingkat kematian larva udang pada semua perlakuan. Hal ini diduga karena kondisi dari larva udang yang lemah sehingga pada kontrol (tanpa bakteri) larva udang juga mengalami kematian. Efek bakteri biokontrol tentunya akan lebih terlihat seandainya larva udang yang digunakan dalam kondisi yang baik dan bebas bakteri patogen. Sulitnya mendapatkan larva udang yang bebas patogen (pathogens free larvae) merupakan salah satu penyebab seringnya mendapatkan data-data yang kurang akurat pada uji bioessay semacam ini. Seperti halnya dalam penelitian ini larva udang yang digunakan sudah mengandung bakteri yang berasal dari kelompok Vibrio spp. yang tumbuh pada media TCBS Agar (warna hijau dan kuning meskipun tidak berpendar) pada konsentrasi $10^{1}-10^{2} \mathrm{cfu} / \mathrm{ekor}$, sehingga mempengaruhi efektivitas bakteri biokontrol dalam menekan kematian larva udang. Hal lain yang diduga menyebabkan tidak adanya perbedaan tingkat kematian larva udang pada perlakuan menggunakan isolat BL542 dan tanpa isolat BL542 adalah karena virulensi MR5339 pada larva udang windu menurun dibandingkan pada saat diisolasi. Ada kecenderungan bahwa semakin lama suatu jenis bakteri patogen udang disimpan, maka patogenisitasnya semakin menurun.

\section{Posisi Relatif Isolat BL542}

Hasil analisis sekuen gen 16S-rRNA dari isolat BL542 disajikan pada Lampiran 1. Dari lampiran tersebut dapat dilihat bahwa isolat BL542 termasuk dalam kelompok Proteobacteria, sub divisi Gamma, famili Alteromonadaceae, genus Pseudoalteromonas, spesies Pseudoalteromonas sp. Edeep-1 dengan indeks kedekatan sebesar $88 \%$. Data sekuen 16S-rRNA Pseudoalteromonas sp. Edeep-1 disajikan pada pada Lampiran 2. Jenis bakteri ini disampaikan atau dilaporkan (submitted) ke EMBL/GenBank/DDBJ database pada tanggal 13 Februari 2001 oleh seorang peneliti dari "Ocean Research Institute, Marine Ecosystem Dynamics", Tokyo, Jepang yang bernama Kumiko Kita-Tsukamoto.

Selain memiliki aktivitas bakterisida, beberapa strain dari Pseudoalteromonas sp. juga telah dilaporkan memiliki aktivitas algisidal seperti Pseudoalteromonas $\mathrm{sp}$. strain $\mathrm{Y}$ yang dapat menurunkan blooming algae (Lovejoy et al., 1998). Sedangkan Pseudoalteromonas $\mathrm{sp}$. strain A28 yang dapat membunuh Skeletonema costatum strain NIES-324 secara in vitro dalam cawan petri merupakan penghasil serin protease yang diproduksi secara ektraseluler (Lee et al., 2000).

\section{KESIMPULAN}

Isolat BL542 termasuk bakteri gram negatif yang berbentuk batang, tidak patogen terhadap udang windu, dan berpotensi sebagai penghasil bakterisida terutama untuk Vibrio harveyi penyebab vibriosis pada udang windu. Hasil analisis sekuen gen penyandi 16S-rRNA, diketahui bahwa isolat BL542 memiliki kemiripan (88\%) dengan Pseudoalteromonas sp. Edeep-1. 


\section{DAFTAR PUSTAKA}

Abrahm, T.J. 2004. Antibacterial marine bacterium deter luminous vibriosis in shrimp larvae. NAGA. Worldfish Center Quarterly, 27(3): 28-31.

Ahmad, T., E. Suryati, and Muliani. 1995. Screening sponge for bactericide to be use in shrimp culture. Ind. Fish. Res. J., 1: 1-10.

Austin B. and J.G. Day. 1990. Inhibition of prawn pathogenic Vibrio spp. By a commercial spray-dried preparation of Tetraselmis suecica. Aquaculture, 90: $389-392$.

Chanratchakool, P., J.F. Turnbull, S.F. Smith, and C. Limsuwan. 1995. Health Management in Shrimp Ponds. $2^{\text {nd }}$ Edition. Aquatic Animal Health Research Institute. Department of Fisheries. Kasetsart University Campus. Bangkok, $111 \mathrm{pp}$.

Chythanya, R., D.K.Nayak, and M.N. Venugopal. 1999 Antibiotic resistance in aquaculture. News from around the world. Infofish Intermational, 6: 30-32.

Devaraja, T.N., S.K. Otta, G. Shubha, I. Karunasagar, P. Tauro, and I. Karunasagar. 1998. Immunostimulantion of shrimp through oral administration of Vibrio bacteri and yeast glucan. In Flegel TW. (Ed.). Advances in shrimp biotechnology. National Center for Genetic Engineering and Biotechnology, Bangkok, p. 167-170.

Devaraja, T.N., F.M. Yussoff, and M. Shariff. 2002. Changes in bacterial populations and shrimp production in ponds treated with commercial microbial products. Aquaculture, 206: 245-256.

Hadioetomo, R.S. 1993. Mikrobiologi Dasar dalam Praktek: Teknik dan Prosedur Dasar Laboratorium. PT Gramedia, Jakarta, p. 62-68.

Hala, Y. 1999. Penggunaan Gen Penanda Molekular untuk Deteksi Pelekatan dan Kolonisasi Vibrio harveyi pada Larva Udang Windu (Penaeus monodon) [Disertasi]. Bogor. Institut Pertanian Bogor, Program Pascasarjana, $91 \mathrm{pp}$.

Hameed, A.S.S. 1995. Susceptibility of three Penaeus species to a Vibrio campbelli-like bacterium. J. World Aqua. Soc., 26: 315-319.

Haryanti, K. Sugama, S. Tsamura, and T. Nishijima. 2000. Vibriostatic bacterium isolated from seawater: Potentiality as probiotic agent in the rearing of Penaeus monodon larvae. Ind. Fish. Res. J., 6: 26-32.

Itami, T., and Y. Takahashi. 1991. Survival of larval giant tiger prawns Penaeus monodon after addition of killed vibrio cell to a microencapsulated diet. J. Aqua Anim. Health, 3: 151-152.

Jiravanichpaisal, P., T. Miyazaki, and C. Limsuwan. 1994. Histopathology, biochemistry, and pathogenecity of Vibrio harveyi infecting black tiger prawn Penaeus monodon. J. Aqua. Anim. Health, 6: 27-35.

Karunasagar, I., R. Pai, G.R. Malathi, and I. Karunasagar. 1994. Mass mortality of Penaeus monodon larvae due to antibiotic-resistant Vibrio harveyi infection. Aquaculture, 128: 203-209.

Lavilla-Pitogo, C.R., L.L. Baticados, E.R. cruz Lacierda, and L.D.de la Pena. 1990. Occurence of luminous bacterial diseases of Penaeus monodon larvae in the Philippines. Aquaculture, 91: 1-13.
Lavilla-Pitogo, C.R., L.J. Albright, and M.G. Paner. 1998. Will microbial manipulation sustain the ecological balance in shrimp (Penaeus monodon) hatcheries?. In Flegel T.W. (Ed.). Advances in Shrimp Biotechnology. National Center for Genetic Engineering and Biotechnology, Bangkok, p. 185-192

Lee, S.O., J. Kato, N. Takiguchi, A. Kuroda, T. Ikeda, A. Mitsutani, and $\mathrm{H}$. Ohtake. 2000. Involvement of an Extracellular protease in algicidal activity of the marine bacterium Pseudoalteromonas sp. Strain A28. Appl. Environ. Microbiol., 66: 4,334-4,339.

Lovejoy, C., J.P. Bowman, and G.M. Hallegraeff. 1998. Algicidal effects of a novel marine Pseudoalteromonas isolat (class proteobacteria, gamma subdivision) on harmful algal bloom species, of the genera Chattonela, Gymnodinium, and Heterosigma. Appl. Environ. Microbiol., 64: $2,806-2,813$

Maeda, M. 1999. Microbial Proses in Aquaculture. National Research Institute of Aquaculture. Nansei, Mie. 516-0193. Japan, 102 pp.

Manefield, M., L. Harris, S.A. Rice, R.D. Nys, and S. Kjelleberg. 2000. Inhibition of luminescence and virulence in the black tiger prawn (Penaeus monodon) pathogen Vibrio harveyi by intracellular signal antagonists. Appl. Environ. Microbiol., 5: 2,079-2,084.

Marchesi, J., R.T. Sato, A.J. Weightman, T.A. Martin, J.C. Fry, S.J. Hiom, and W.G. Wade. 1998. Design and evaluation of useful bacterium-spesifik PCR primers that amplify genes coding for bacterial 16S-rRNA. Appl. Environ. Microbiol., 64: 795-799.

Muir, P. 1996. Identification of Vibrio and Pseudomonas Bacteria. Department of Microbiology, Biomedical and Tropical Veterinary Science. James Cook University of North Queensland. Australia, $6 \mathrm{pp}$.

Muliani, M. Atmomarsono, dan M.I. Madeali. 1998a. Pengaruh penggunaan kekerangan sebagai biofilter terhadap kelimpahan dan komposisi jenis bakteri pada budi daya udang windu (Penaeus monodon) dengan sistem resirkulasi air. J. Pen. Per. Indonesia, 3: $54-61$.

Muliani, E. Suryati, and T. Ahmad. 1998b. Penggunaan ekstrak spons untuk penanggulangan bakteri Vibrio spp. pada udang windu Penaeus monodon. J. Pen. Per. Indonesia, 1: 108-115.

Muliani, Nurbaya, A. Tompo, dan M. Atmomarsono. 2004a. Eksplorasi Bakteri Filosfer dari Tanaman Mangrove sebagai Bakteri Probiotik Pada Budidaya Udang Windu Penaeus monodon. J. Pen. Per. Indonesia, 2: 51-61.

Muliani, Nurbaya, A. Tompo, Nurhidaya, S. Endang, M.I. Madeali, dan M. Atmomarsono. 2004b. Ekplorasi bakteri tambak sebagai bakteri probiotik pada budidaya udang windu. Laporan hasil penelitian Tahun Anggaran 2004. Balai Riset Perikanan Budidaya Air Payau, 20 pp.

Oclarit, J.M., S. Ohta, K. Kamimura, Y. Yamaoka, and S. Ikegami. 1994. Production of an antibacterial agen, o-Aminiphenol, by a bacterium isolated from marine sponge, Adocia sp. Fish. Sci., 60: 559-562. 
Rengpipat, S., S. Rukpratanporn, S. Piyatiratitivorakul, and P. Menasveta. 1998. Probiotics in Aquaculture: A case study of probiotics for larvae of black tiger shrimp (Penaeus monodon). In Flegel T.W. (Ed.). Advances in shrimp biotechnology. National Center for Genetic Engineering and Biotechnology, Bangkok, p. 177-181.

Rosa, D., Zafran, I. Taufik, and M.A. Girsang. 1997. Pengendalian Vibrio harveyi secara biologis pada larva udang windu (Penaeus monodon): I. Isolasi Bakteri Penghambat. J. Penel. Perik. Indonesia, 3: $1-10$.

Ruangpan, L. 1998. Luminous bacteria associated with shrimp mortality. In Flegel T.W. (Ed.). Advances in shrimp biotechnology. National Center for Genetic Engineering and Biotechnology, Bangkok, p. 205-211.

Salfira. 1998. Pengaruh Pemberian LPS (Lipopolisakarida) dari Dinding Sel Bakteri Vibrio harveyi terhadap Gambaran Sistem Kekebalan Nonspesifik pada Udang Windu (Penaeus monodon Fab.) [Tesis]. Program Pascasarjana Institut Pertanian Bogor. Bogor.

Steel, R.G.D. and J.H. Torrie. 1981. Principles and Procedures of statistics. A Biometrical Approach $\left(2^{\text {nd }}\right.$ edition). International Student Edition. McGraw-Hill International Book Company, $633 \mathrm{pp}$.
Sung, H.H., G.H. Kou, and Y.L. Song. 1994. Vibriosis resistance induced by glucan treatment in tiger shrimp (Penaeus monodon). Fish Phatol., 1: 11-17.

Suryati, E., Rosmiati, W. Moka, and Y. Hala. 2000. Hydrozoan Aglaophenia sp. Bioactive Substance Analysis for Bactericide. Ind. Fish. Res. J., 6: 55-61.

Suwanto, A., Yogiara, D. Suryanto, 1. Tan, and E. Puspitasari. 2000. Selected protocols. Training Course on Advances in Molecular Biology Techniques to Assess Microbial Diversity. Bogor, $28 \mathrm{pp}$.

Sze, P.C. 2000. Antibiotic use in aquaculture: The Malaysian perspective. News from around the world. Infofish Intemational, 2: 25-29.

Tjahjadi, M.R, S. L. Angka, and A. Suwanto. 1994. Isolation and evaluation of marine bacteria for biocontrol of luminous bacterial diseases in tiger shrimp larvae (Penaeus monodon Fab.). Aspac. J. Mol. Biol. Biotechnol., 2: 347-352.

Vargas-Albores, F., J. Hernandez-Lopez, T. GallasGalvan, K. Montano-Perez, F. Jimenez-Vega, and G. Yepiz-Plascencia. 1998. Activation of shrimp cellular defence fungtions by microbial products. In Flegel T.W. (Ed.). Advences in shrimp biotechnology. National Center for Genetic Engineering and Biotechnology, Bangkok, p. 161-166. 


\section{Lampiran 1. Data hasil FASTA isolat BL542 Appendix 1. Data Result of isolat BL542 FASTA}

FASTA searches a protein or DNA sequence data bank version 3.3t09 May 18, 2001 Please cite: W.R. Pearson \& D.J. Lipman PNAS (1988) 85:2444-2448@:1-: $628 \mathrm{nt}$ EMBOSS_001 vs EMBL Prokaryote librarysearching /ebi/services/idata/fastadb/em_pro library366331426 residues in 122962 sequences statistics extrapolated from 60000 to 91471 sequences Expectation_ $\mathrm{n}$ fit: rho $(\ln (x))=0.3949+/-0.000216 ; m u=56.5105+/-0.018$ mean_var $=1042.7002+/-229.356$, 0's: 8 Z-trim: 14760 B-trim: 1950 in 2/75 Lambda= 0.0397FASTA (3.39 May 2001) function [optimized, +5/-4 matrix (5:-4)] ktup: 6 join: 52, opt: 37, gap-pen: $-16 /-4$, width: 16 Scan time: 13.090 The best scores are: opt bits E(91471)EM_PRO:AB055794 AB055794 Pseudoalteromonas sp. (1498) [f] 2326 151 4.3e-35EM_PRO:AF159671 AF159671 Uncultured marine eub (1014) [f] 2276 147 4.6e-34EM_PRO:UGA311965 AJ311965 Uncultured gamma pro (1412) [f] 2211 144 4.4e-33EM_PRO:AF300975 AF300975 Bacterium C16S 16S ri (1497) [f] 2156141 3.7e-32EM_PRO:AB022707 AB022707 Adapted facultatively (595) [f] 2170140 5.3e-32EM_PRO:AARRNA16S X82135 A. aurantia 16S rRNA ge (1436) [f] 2142 1406.7e-32EM_PRO:ACRNA16S X82137 A.citrea 16S rRNA gene (1436) [f] $21421406.7 \mathrm{e}-32 \mathrm{EM}$ _PRO:AF366040 AF366040 Marine gamma proteoba (634) [f] 2152139 1e-31EM_PRO:AB022206 AB022206 Marine adapted facult (614) [f] 2151 139 1.1e-31EM_PRO:PSP414129 AJ414129 Pseudoalteromonas sp (651) [f] 2141 139 1.5e-31EM_PRO:AF118018 AF118018 Pseudoalteromonas sp. (1495) [f] 2112138 2.1e-31EM_PRO:AF343945 AF343945 Pseudoalteromonas sp. ( 741) [f] 2123138 2.8e-31EM_PRO:AY028199 AY028199 Marine bacterium Tw-4 (1448) [f] 2106138 2.8e-31EM_PRO:AF227238 AF227238 Pseudoalteromonas sp. (1502) [f] 2100138 3.4e-31EM_PRO:AB029824 AB029824 Pseudoalteromonas sp. (1492) [f] 2100138 3.4e-31EM_PRO:HV15114 U15114 Hydrothermal vent eubact (1461) [f] 2100138 3.5e-31EM_PRO:UBA295713 AJ295713 Polar sea bacterium (1494) [f] 2091 137 4.9e-31EM_PRO:AF172991 AF172991 Pseudoalteromonas sp. (1386) [f] 2089137 5.7e-31EM_PRO:AF172989 AF172989 Pseudoalteromonas sp. (1365) [f] 2088137 6.1e-31EM_PRO:AF172990 AF172990 Pseudoalteromonas sp. (1384) [f] 2073136 1.1e-30EM_PRO:AF317746 AF317746 Unidentified bacteriu (1466) [f] 2071 136 1.1e-30EM_PRO:AF366001 AF366001 Marine CFB-group bact (627) [f] 2082135 1.7e-30EM_PRO:AF343936 AF343936 Pseudoalteromonas sp. ( 740) [f] $20761351.8 \mathrm{e}-30$ EM_PRO:AF366039 AF366039 Marine gamma proteoba(627) [f] 2079135 1.9e-30EM_PRO:PSU85855 U85855 Pseudoalteromonas sp. M (1449) [f] 2055135 2.1e-30EM_PRO:AF118019 AF118019 Pseudoalteromonas sp. (1497) [f] 2052135 2.3e-30EM_PRO:AF022407 AF022407 Pseudoalteromonas sp. (1464) [f] 2049135 2.7e-30EM_PRO:AF038846 AF038846 Pseudoalteromonas gra (1515) [f] 2046135 2.9e-30EM_PRO:AB055788 AB055788 Pseudoalteromonas sp. (1386) [f] 2039 134 4.2e-30EM_PRO:AD16SRRNA X82138 A.denitrificans $16 \mathrm{~S} r R \quad$ (1424) [f] 2030134 5.8e-30EM_PRO:AB055785 AB055785 Pseudoalteromonas sp. (1499) [f] 2025133 6.7e-30EM_PRO:PSP391204 AJ391204 Pseudoalteromonas sp (1530) [f] 2023 133 7.2e-30EM_PRO:AF297958 AF297958 Pseudoalteromonas sp. (1483) [f] 2023 133 7.4e-30EM_PRO:AF030381 AF030381 Pseudoalteromonas sp. (1471) [f] 2023 133 7.4e-30EM_PRO:AF297662 AF297662 Pseudoalteromonas pis (1462) [f] 2023 133 7.5e-30EM_PRO:AF297959 


\section{Lampiran 1. Lanjutan}

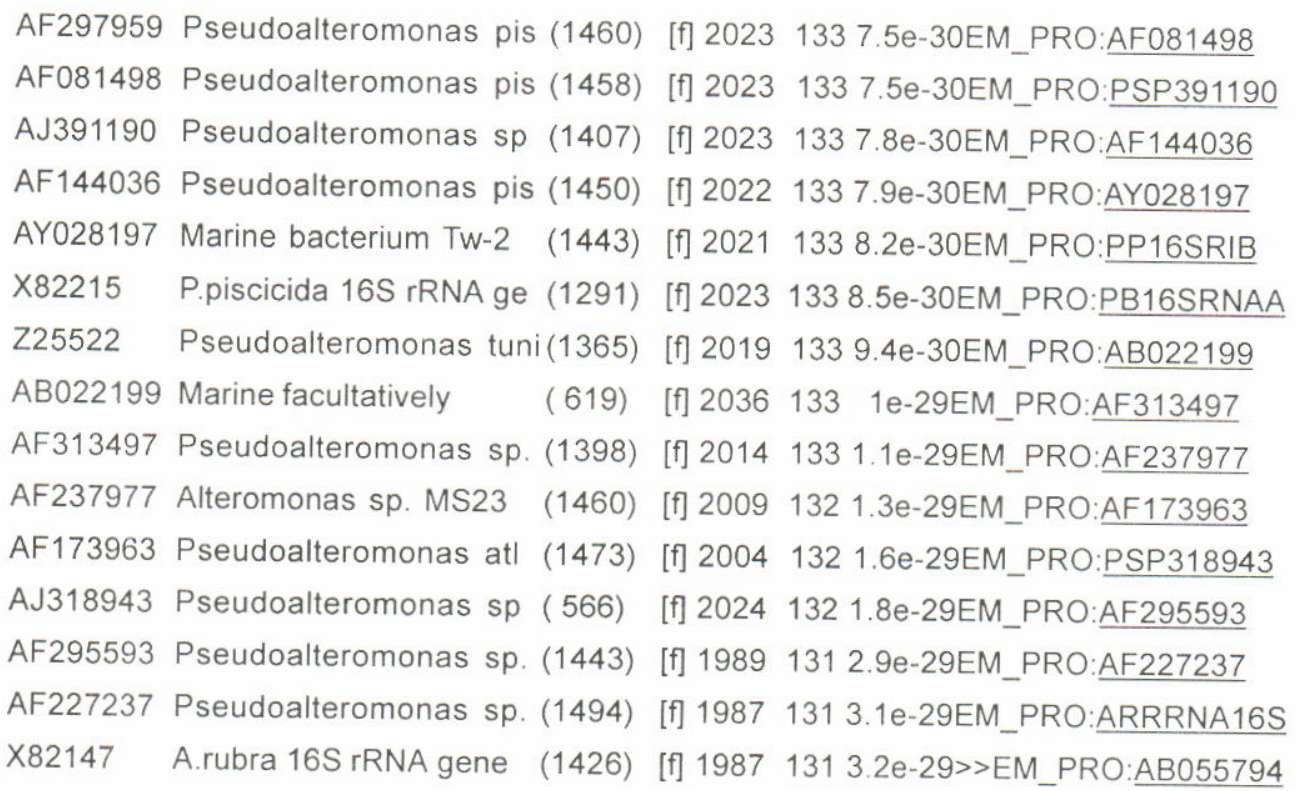

AB055794 Pseudoalteromonas sp. Edeep-1 (1498 nt) initn: 1434 init1: 536 opt:

2326 Z-score: 751.9 bits: $150.6 \mathrm{E}()$ ) $4.3 \mathrm{e}-35 \mathrm{88.291 \%}$ identity $(95.060 \%$

ungapped) in 632 nt overlap (8-628:50-671) 
Lampiran 2. Data sekuen 16S-rRNA Pseudoalteromonas sp. Edeep-1 ID AB055794 standard; DNA; PRO; 1498 BP.

$x x$

AC AB055794;

$X X$

SV AB055794.1

$X X$

DT 20-FEB-2001 (Rel. 66, Created)

DT 20-FEB-2001 (Rel. 66, Last updated, Version 1)

$\mathrm{XX}$

DE Pseudoalteromonas sp. Edeep-1 gene for $16 \mathrm{~S}$ rRNA.

$x x$

$\mathrm{KW}$.

$x x$

OS Pseudoalteromonas sp. Edeep-1

OC Bacteria; Proteobacteria; gamma subdivision; Alteromonadaceae;

OC Pseudoalteromonas.

$x x$

$\mathrm{RN}$ [1]

RP $1-1498$

RA Kita-Tsukamoto K., Radjasa O.K.;

RT ;

RL Submitted (13-FEB-2001) to the EMBL/GenBank/DDBJ databases.

$\mathrm{RL}$ Kumiko Kita-Tsukamoto, Ocean Research Institute, Marine Ecosystems

RL Dynamics; 1-15-1 Minamidai, Nakano, Tokyo 164-8639, Japan

RL (E-mail:tukamoto@ori.u-tokyo.ac.jp, Tel:81-3-5351-6484, Fax:81-3-5351-6482)

$X X$

$\mathrm{RN}$ [2]

RA Radjasa O.K., Urakawa H., Kita-Tsukamoto K., Ohwada K.;

RT "Characterization of psychrotrophic bacteria in the surface and deep-sea

RT waters from the north-western Pacific Ocean based on 16S rDNA analysis";

$\mathrm{RL}$ Unpublished.

$X X$

$\mathrm{FH}$ Key Location/Qualifiers

$\mathrm{FH}$

FT source 1..1498

FT /db_xref="taxon: $152523 "$

FT Isequenced_mol="DNA"

FT Iorganism="Pseudoalteromonas sp. Edeep-1"

FT $\quad /$ strain="Edeep-1"

FT IRNA 1..1498

FT /product="16S rRNA"

$x X$

SQ Sequence $1498 \mathrm{BP} ; 390$ A; 333 C; 454 G; $321 \mathrm{~T} ; 0$ other;

cgctggcggc aggcctaaca catgcaagtc gagcggtaac

$\begin{array}{lllll}\text { cttgaggtgg gggacaacag ttggaaacga ctgctaatac cgcataatgt ctacggacca } & 180\end{array}$

aagggggctt cggctctcgc ctttagattg gcccaagtgg gattagctag ttggtgaggt 240

aatggctcac caaggcgacg atcctagct ggttgagag gatgatcagc cacactggga 300 


\section{Lampiran 2. Lanjutan}

$\begin{array}{llllllr}\text { ctgagacacg } & \text { gcccagactc } & \text { ctacgggagg } & \text { cagcagtggg } & \text { gaatattgca } & \text { caatgggcgc } & 360 \\ \text { aagcctgatg } & \text { cagccatgcc } & \text { gcgtgtgtga } & \text { agaaggcctt } & \text { cgggttgtaa } & \text { agcacttca } & 420 \\ \text { gtgcagggag } & \text { gaaaggctta } & \text { gtagttaata } & \text { cctgctagct } & \text { gtgacgttac } & \text { tcacagaaga } & 480 \\ \text { agcaccggct } & \text { aactccgtgc } & \text { cagcagccgc } & \text { ggtaatacgg } & \text { agggtgcgag cgttaatcgg } & 540 \\ \text { aattactggc } & \text { cgtaaagcgt } & \text { acgcaggtgg } & \text { tttgttaagc } & \text { gagatgtgaa agcccgggc } & 600 \\ \text { tcaacctggg } & \text { aactgcattt } & \text { cgaactggca } & \text { aactagagtg } & \text { tgatagaggg tggtagaatt } & 660 \\ \text { tcaggtgtag } & \text { cggtgaaatg } & \text { cgtagagatc } & \text { tgaaggaata } & \text { ccgatggcga aggcagccac } & 720 \\ \text { ctgggttaac } & \text { actgacgctc } & \text { atgtacgaaa } & \text { gcgtggggag } & \text { caaacaggat tagatacct } & 780 \\ \text { ggtagtccac } & \text { gccgtaaccg } & \text { atgtctacta } & \text { gaagctcgga } & \text { acctcggttc } & \text { tgttttcaa } & 840 \\ \text { agctaacgca } & \text { ttaagtagac } & \text { cgcctgggga } & \text { gtacggccgc } & \text { aaggttaaaa ctcaaatgaa } & 900 \\ \text { ttgacggggg } & \text { cccgcacaag } & \text { cggtggagca } & \text { tgtggttaa } & \text { ttcgatgcaa cgcgaagaac } & 960 \\ \text { cttacctaca } & \text { cttgacatac } & \text { agagaactta } & \text { ctagagatgg } & \text { tttggtgctt } & \text { cgggaactct } & 1020 \\ \text { gatacaggtg } & \text { ctgcatggct } & \text { tgctgtcaag } & \text { ctcggtgttg } & \text { tgaaaatgtt cgggtaaagt } & 1080 \\ \text { cccgcaacga } & \text { gcgcaacccc } & \text { tgatccttag } & \text { ttgctagcag } & \text { taatgctgag } & \text { aaactctaag } & 1140 \\ \text { gagactgccg } & \text { gtgataaacc } & \text { ggaggtaagg } & \text { tggggacgac } & \text { gtcaagtcca } & \text { tccatggccc } & 1200 \\ \text { ttacgtgtag } & \text { ggctacacac } & \text { gtgctacaat } & \text { ggcgcataca } & \text { gagtgtctgc } & \text { gaactcgcga } & 1260 \\ \text { gagtaagcga atcacttaaa } & \text { gtgcgtcgta } & \text { gtccggattg } & \text { gagtctgcaa } & \text { ctcgactcca } & 1320 \\ \text { tgaagtcgga } & \text { atcgctagta } & \text { atcgcgtatc } & \text { agaatgacgc } & \text { ggtgaatacg } & \text { ttcccgggcc } & 1380 \\ \text { ttgtacacac } & \text { cgcccgtcac } & \text { accatgggag } & \text { tgggttgctc } & \text { cagaagtaga tagtctaacc } & 1440 \\ \text { ctcgggagga } & \text { cgtttaccac } & \text { ggagtgattc } & \text { atgactgggg } & \text { tgaagtcgta acaaggta } & 1498\end{array}$


